\title{
CHAPTER 1 \\ THEORETICAL AND METHODOLOGICAL ASPECTS OF RESEARCHING STAFF STIMULATION SYSTEMS
}

\subsection{Labor incentives as a basic element of personnel management}

The implementation of economic reforms in Russia has led to the fact that the position of the organization has radically changed, its status has been transformed.

Currently, there have been changes in the relationship between the manager and subordinates. All this sharply raised the question of how to effectively and efficiently carry out management in the new conditions. «Until recently, the very concept of «personnel management» was absent in our management practice. The management system of each organization had only a functional subsystem for personnel management and social development of the team, but most of the work on personnel management was performed by line managers of departments» ${ }^{1}$. The personnel work carried out at enterprises has ceased to meet the requirements of the time, and a new science has come to replace it - personnel management.

Human resource management of an organization is understood by us as a purposeful activity of the management of the organization, heads and specialists of departments to develop the concept and strategy of the personnel use policy, principles and methods of using personnel ${ }^{2}$.

Personnel management ${ }^{3}$ of an organization covers a wide range of functions:

- recruitment, selection and recruitment of personnel;

- business assessment of personnel during admission, certification, selection;

- vocational guidance and work adaptation;

- stimulation of labor activity of personnel and its use;

- work organization and adherence to business ethics;

- conflict and stress management;

- ensuring the safety of personnel;

- management of innovations in personnel work;

- training, professional development and retraining of personnel;

- management of business career and service and professional advancement;

- managing the behavior of personnel in the organization;

- management of social development;

- release of personnel.

All these components are closely intertwined and are aimed, first of all, at

${ }^{1}$ See: Odegov Yu.G., Zhuravlev P.V. Personnel management: Textbook for universities. - M.: Finstatinform, 1997. - P. 46.

${ }^{2}$ See: Organization personnel management: Textbook / Edited by A.Ya. Kibanov. - M.: INFRA-M, 2004. - P. 79.

${ }^{3}$ Personnel management is a field of activity typical for all organizations, the main task of which is to provide the organization with personnel and its purposeful use. 
creating such working conditions that would contribute to the fullest possible disclosure of the employee's labor potential.

The unique professional core of human resources is the main competitive advantage of any company seeking to strengthen its position in the market. In the 21 st century this provision will become the law of successful entrepreneurship, since only mobile personnel oriented towards continuous development and improvement can adapt to unpredictable and often ambiguous changes in the market environment.

The turn of the 20th and 21 st centuries saw changes in corporate governance associated with the globalization of markets and industrial structure, with shifts in the composition of jobs and labor force demographics, with a focus on high income for owners. These changes, which affected not only the business as such, but also the process of personnel work in companies, can be summarized as follows ${ }^{4}$ :

- from autonomous self-sufficiency - to unlimited partnership;

- from hierarchical and / or centralized structures - to plastic and decentralized structures;

- from patriarchal models of management - to delegation of powers;

- from a focus on large volumes and low cost - to focus on quality, speed and innovation;

- from error-free performance to measurable improvements;

- from a closed organizational system to an open system.

The changes that have taken place could not but affect such an important resource of any organization as a person: the changes found their expression in the approach to personnel, in the understanding of the fact that a radical revision of labor management methods is necessary, since both the work itself and the subject performing it have changed. The changes that have occurred can be expressed in the following facts ${ }^{5}$ :

- narrow specialization and limited responsibility for the assigned work was replaced by broad professional and job profiles;

- flexible choice of the trajectory of professional development has replaced a clearly planned career path;

- from evading feedback from subordinates of the organization came to its active search;

- secret consideration of factors of success, vacancies and selection of specialists was replaced by an open discussion of the level of competence of employees, available vacancies and ways to fill them.

It should be noted that in the course of social reforms, relations have changed not only along the line «leader - subordinate», but also on the line «subordinate - leader». First of all, this is reflected in the concept of personnel management ${ }^{6}$,

${ }^{4}$ See: Odegov Yu.G., Zhuravlev P.V. Spec. works. - P. 52.

${ }^{5}$ Ibid. - P. 54.

${ }^{6}$ See: Organization personnel management: Textbook / Edited by A.Ya. Kibanov. - M.: INFRA-M, 2004. - P. 90. 
in the system of theoretical and methodological views on understanding and defining the essence, content, goals, objectives, criteria, principles and methods of personnel management, as well as organizational and practical approaches to the formation of a mechanism for its implementation in specific conditions of functioning of organizations.

Now it is based on the following factors:

1. the growing role of the employee's personality;

2. knowledge of his motivational attitudes;

3.the ability to form and direct them in accordance with the tasks facing the organization ${ }^{7}$.

Understanding the fact that each person is unique and is, first of all, a person with his own characteristics, desires and needs, made it possible to determine the individual differences between employees, which can be divided into three large groups:

1. demographic characteristics (age, gender, etc.);

2. competence (inclinations and abilities, etc.);

3. psychological characteristics (value system, attitude to work, character, etc.).

Demographic characteristics define a person in terms of his physiological differences, which may predetermine his other characteristics in the future. Competence includes the abilities and inclinations of a person that are necessary for him in the work. Abilities can be defined as personality characteristics that allow one to perform certain labor functions. Psychological characteristics are determined by the presence in individuals of various systems of life values, motives of behavior, etc. These characteristics in a certain way predetermine and form the motivational structure of the employee's person ${ }^{9}$.

All of the listed individual differences leave their imprint on the performance of work tasks and functions, on the type of work behavior of the employee. Researchers note that managers who do not take into account the specific characteristics of workers are faced with the problem of low labor productivity, with a lack of personal interest in the results of labor among staff.

Each named feature can affect labor productivity through the impact on human abilities. It is the consideration of these features and unique personality traits that makes it possible to form appropriate labor behavior among staff. Such a differentiated approach to the employee makes it possible to use his unique abilities and individual personality characteristics for the benefit of the organization. As a result of this approach, the organization forms the work behavior it needs, and the ${ }^{7}$ Ibid. - P. 91.

${ }^{8}$ See: Organizational Behavior: A Textbook for Universities. Edited by G.R. Latfullina, O. N. Gromova. - SPb.: Peter, 2006. - P. 97.

${ }^{9}$ The motivational structure of a person is a set of motives associated and conditioned by the semantic motive of activity, an internal determinant of behavior that determines its general orientation. The motivational structure of a person is the main criterion in determining the type of motivation of an individual. 
staff gets the opportunity to develop their abilities and meet their needs.

As a result of the evolution of approaches to managing a person in an organization, «the view of labor as a conscious, purposefully directed activity, the application of common efforts by people to create useful products that go to satisfy their material and spiritual needs, has now been established. At the same time, work is a means of self-expression and self-affirmation of the individual, the realization of his experience, intellectual and creative potential $\rangle^{10}$.

With the approach of society to the information age, the role of the individual has significantly increased in all spheres of life. "A person becomes an active subject of new social relations, and therefore a subject of social planning at all levels, including at the level of organizations ${ }^{11}$. As a result, economic relations are increasingly leaning towards social guidelines, «and the existence and success of organizations depend on the development of an integral system of incentives for the intensification of human activity» ${ }^{12}$.

Today, management practice has a huge arsenal of various means and methods of incentives, but there is still no incentive mechanism that would smooth out the contradictions between the goals of the employee and the employer in the distribution of the benefits of the organization. This was clearly proved by $\mathrm{J}$. Habermas ${ }^{13}$, who investigated the opposition of the human life world and the social system (organization).

All elements of personnel management, from hiring to dismissal, constitute a kind of labor incentive policy, be it personnel adaptation, business assessment or career guidance. The attractiveness of the organization for potential employees, its competitiveness in the labor market for qualified personnel and its stability and success directly depend on how these mechanisms work.

There is a direct and very close relationship between the stimulation of labor and the results of labor. Stimulation of labor can lead to changes in labor indicators, both in the direction of improvement and deterioration. It all depends on how the incentive system is developed, how it is promoted in the team and how the employee himself is perceived according to his ideas and expectations. It should be noted that at this stage, scientists and practitioners began to pay more and more attention to the issues of incentives and motivation. An example of this is various studies in the field of motivation, numerous monographs and articles written on this topic, holding conferences and training seminars.

Analysis of scientific literature on management theory, management, personnel management, management psychology shows that research in the field of staff

\footnotetext{
${ }^{10}$ See: Organization personnel management: Textbook / Edited by A.Ya. Kibanov. - P. 18.

${ }^{11}$ See: Kuznetsov A.L., Zakharov N.L. Management of the social development of the organization. M.: INFRA-M, 2006. - P. 62.

${ }^{12}$ Ibid. - P. 62.

${ }^{13}$ See: Habermas $J$. Relations between the system and the life world in the conditions of late capitalism // Theory and history of economic and social institutions and systems. Structures and institutions. - 1993. - Vol. 1. - Issue. 2.
} 
motivation and incentives is carried out, as a rule, in established, classical forms. Research of personnel incentive systems is carried out mainly in the following scientific areas: (1) theories of motivation; (2) theoretical approaches aimed at solving applied problems of developing labor incentive mechanisms; (3) a special direction is made up of scientific works devoted to the effectiveness of personnel management in an organization; (4) in the framework of the study of quality management as a new direction of modern management.

The first direction is a fundamental theoretical base, including methodological developments, various theories of motivation. First of all, these are scientific works devoted to the development of various theories of motivation: the works of A. Maslow ${ }^{14}$, K. Alderfer ${ }^{15}$, D. McClelland ${ }^{16}$, F. Herzberg ${ }^{17}$, L. Porter-Lawler ${ }^{18}$, B V. Vroom ${ }^{19}$, D.M. McGregor ${ }^{20}$, B. Skinner ${ }^{21}$. A significant contribution to the theory and methodology of stimulation and motivation of labor was made by such outstanding social scientists as M. Weber ${ }^{22}$, K. Levin ${ }^{23}$, A.N. Leontiev ${ }^{24}$, E. Durkheim $^{25}$, P. Blau ${ }^{26}$, G. Homans ${ }^{27}$ and others. Measures to increase motivation and stimulate labor by improving the socio-psychological climate in the organization and smoothing out industrial conflicts are analyzed in the monographs of C. Bernard, B.S. Rowntree, M.P. Follet ${ }^{28}$.

The second direction - the solution of applied problems of the development of an incentive mechanism, in fact, is the concretization of the first direction in the designated scientific field. Here the attention of researchers is directed to the consideration of the formation and functioning of motivation, the typology of motivation, its strength, focus, employee satisfaction with their work. Among these studies, the works of scientists from the Research Institute of Labor of the

\footnotetext{
${ }^{14}$ See: Maslow A. Motivation and personality. - M., 1999.

${ }^{15}$ Alderfer C.P. Existence, Relatedness and Growth: Human Needs in Organizational Settings. N.Y., 1972.

${ }^{16}$ McClelland D.C. Power: The Inner Experience. - N.J., 1975.

${ }^{17}$ Herzberg F., Miner M.U. Motivation to work and production motivation // Sociological research. 1990. - No. 1 .

${ }^{18}$ See: Porter L.W., Lawler E.E. Managerial attitudes and performance. - Homewood, 1968; Egorshin A.P. Work motivation. - N. Novgorod: NIMB, 2003.

${ }^{19}$ Vroom V.H. Motivation in Management. - N.Y., 1965.

${ }^{20}$ McGregor D. The human Side of Enterprise. - N.Y., 1960.

${ }^{21}$ Skinner B.F. The technology of teaching. - N.Y., 1968.

${ }^{22}$ Weber M. Basic sociological concepts // Selected works. - M., 1990.

${ }^{23}$ Levin K. A Dynamic Theory of Personality. - N.Y., 1935; Levin K. Principles of Topological Psychology. L. 1936; Levin K. Field Theory in Social Science. - N.Y., 1951.

${ }^{24}$ Leontiev A.N. Activity, consciousness, personality // Selected psychological works. - In 2 volumes. - M., 1983.

${ }^{25}$ Durkheim E. Sociology. Its subject, method, purpose. - M.: Canon +, 2006.

${ }^{26}$ Blau P.M. Exchange and power in social life. - N.Y., 1964.

${ }^{27}$ Homans G. Social behavior: its elementary forms. - N.Y.: Harcourt, Brace, 1961.

${ }^{28}$ Follet M.P. Giving orders. In the book: Classics of Public Administration Theory: American School / Edited by J. Schaffritz, A. Hyde. - M.: Publishing house of Moscow State University, 2003.
} 
$\overline{\text { Ministry of Labor of the Russian Federation I.F. Belyaeva }{ }^{29} \text {, E. D. Katulsky and }}$ others.$^{30}$ The research of the classics of management and management practitioners F. Taylor, G. Ford ${ }^{31}$, E. Mayo ${ }^{32}$, M. Albert, M. Mescon, F. Khedouri ${ }^{33}$ and others are devoted to the solution of applied problems of motivation, its formation and functioning, and the development of an incentive mechanism.

It should be noted that in the thirties of the XX century sociology was proclaimed a bourgeois science, and large-scale research was not carried out for a long time. The revival of interest in the problems of motivation and stimulation of labor fell on the 60-80s of the last century and was reflected in the works of A.G. Zdravomyslov and V.A. Yadova ${ }^{34}$, V.G. Podmarkova ${ }^{35}$, S. Ya. Batyshev ${ }^{36}$, Zh.T. Toshchenko ${ }^{37}$ and others. In the works of V.I. Gerchikov ${ }^{38}$, E.A.Utkin ${ }^{39}$, Ya. Eidelman ${ }^{40}$ and others, the features of stimulation and motivation in the transitional Russian society are considered.

Among the domestic scientists who have been studying the influence of the level of material interest on motivation, it should be noted A.K. Gastev ${ }^{41}$, O.A. Yermansky ${ }^{42}$.

In the 60 s of the XX century, special interest was paid to the problems of the scientific organization of labor ${ }^{43}$. During these years, the works of such

\footnotetext{
${ }^{29}$ See: Belyaeva I.F. Labor motivation: Mechanisms of formation and functioning. Change in labor motivation in new conditions. - M.: Research Institute of Labor, 1992.

${ }^{30}$ See: Katulskiy E. «Motivation in the labor market» // Economic issues [Voprosy ekonomiki]. - No. 2, 1997. - P. 92-101; Kibanov A.Ya., Mamed-zade G.A., Rodkina T.A. Personnel Management. Labor regulation. - M.: Exam, 1999.

${ }^{31}$ See: Management is science and art // Collection: Fayol A., Emerson G., Taylor F., Ford G. - M., 1992.

${ }^{32}$ Mayo E. The Social Problems of an Industrial Civilization. - L. 1949.

${ }^{33}$ Mescon M.H., Albert M., Khedouri F. Management. - M.: Delo, 2005.

${ }^{34}$ See: A. G. Zdravomyslov, V. A. Yadov Man and his work in the USSR and after. - M.: Aspect Press, 2003; V.A. Yadov Formation of labor relations in post-Soviet Russia. (Sociological analysis of five cases of Russian management in comparison with the practice of Canada and Germany) - M., IS RAS, Academ. Project, 2004; Zdravomyslov A.G. Needs, interests, values. - M., 1986.

${ }^{35}$ Podmarkov V.G. Man in a labor collective: Problems of sociology of labor/V.G. Podmarkov. - M., 1982.

${ }^{36}$ Batyshev S.Ya. Training of working professionals / S.Ya. Batyshev. - M.: APO, 1995.

${ }^{37}$ Toshchenko Zh.T. A paradoxical person. 2nd ed. - M., Unity-Dana, 2008; Toshchenko Zh.T. Social reserves of labor). - M., 1989.

${ }^{38}$ V.I. Gerchikov Personnel management: An employee is the most effective resource of the company: A textbook for universities. - M.: Infra-M, 2008.

${ }^{39}$ Utkin E.A. Motivational management. - M.: Teis, 2004.

${ }^{40}$ Lapygin Yu.N. Eidelman Ya.L. Motivation for economic activity in the context of the Russian reform. - M., 1996.

${ }^{41}$ Gastev A.K. Trade unions and labor organization. - L., 1924; Gastev A.K. Rationing and organization of labor. - M., 1929.

42 Yermansky O.A. Tasks of the scientific organization of labor and its position. // Bulletin of the socialist academy. 1923. - No. 3.

${ }^{43}$ See: Mukhambetov T.I. Motivational mechanism of labor management. Alma-Ata: Gylym, 1991, pp. 52, 53; Sociology in Russia. - M., 1998.
} 
sociologists as L.N. Kogan ${ }^{44}$, L.V. Sokhan ${ }^{45}$, dedicated to the identification of factors (earnings and labor content) that affect job satisfaction. Another group of issues - labor motivation in the temporal aspect - was addressed by B.M. Teplov and A.S. Makarenko.

The third direction has developed on the basis of research on various mechanisms of motivation and approaches to personnel management. So, in the works of authors such as A.Ya. Kibanov ${ }^{46}$, A.I. Prigogine ${ }^{47}$, V.A. Spivak ${ }^{48}$, investigated the most important aspects of labor motivation, the conditions for the social development of the organization and other components of the labor activity of personnel. The problems of the sociology of labor and incentives are considered in the works of modern scientists: T.I. Zaslavskaya ${ }^{49}$, N.A. Volgin and others ${ }^{50}$.

Among domestic researchers in the field of labor sociology and, in particular, the problems of stimulating and motivating labor activity, A.I. Kravchenko ${ }^{51}$, V.N. Minina ${ }^{52}$, V.I. Dobrenkov ${ }^{53}$, V.S. Magun ${ }^{54}$, A.G. Simakov ${ }^{55}$, V. Ya. Elmeev ${ }^{56}$, V.G. Ovsyannikov ${ }^{57}$, Yu.V. Veselova ${ }^{58}$, E.L. Shershneva ${ }^{59}$, E.V. Kapustkina ${ }^{60}$, T.I. Mukhambetov ${ }^{61}$, Yu.G. Odegov ${ }^{62}$ and others. Work satisfaction has been

\footnotetext{
${ }^{44}$ Kogan L.N. The purpose and meaning of human life. - M., 1984.

${ }^{45}$ Sokhan L.V. Facets of personality // E.A. Yakuba (research and memories). - Kharkov, 2004. - P. 256-259.

${ }^{46}$ Kibanov A.Ya., Zakharov D.K. Formation of a personnel management system. - M.: SAU, 1994.

${ }^{47}$ Prigogine A.I. Contemporary sociology of organizations. - M., 1995.

${ }^{48}$ Spivak V.A. Developmental personnel management. - M.: Neva, 2004.

${ }^{49}$ See: Zaslavskaya T.I., Ryvkina R.V. Sociology of economic life. - M., 1991; Zaslavskaya T.I.
} Societal Transformation of Russian Society: Activity-Structural Concept. - M.: Delo, 2002; Zaslavskaya T.I. Contemporary Russian Society: Social Mechanism of Transformation. Textbook. manual. - M.: Delo, 2004.

${ }^{50}$ Volgin N.A., Volgina O.N. Labor remuneration: Japanese experience and Russian practice. -M.: Publishing and trade corporation «Dashkov and K», 2004.

${ }^{51}$ Kravchenko A.I. History of management. - M., 2003.

${ }^{52}$ Minina V.N. Social programming: theoretical and methodological aspect. - SPb.: Publishing house of SPbSU, 1997.

${ }^{53}$ Dobrenkov V.I. Sociology. Vol. 1-3. - M., 2000.

${ }^{54}$ Magun V.S. Needs and psychology of social activity. - L.: Nauka, 1983.

${ }_{55}^{55}$ Simakov A.G. Labor in Russia of the XX century. - M.: Publishing house MGSU «Soyuz», 1997.

${ }^{56}$ Elmeev V.Ya. Towards a new paradigm of socio-economic development and knowledge of society. - SPb., 1999; Elmeev V.Ya Theory and practice of social development. - SPb., 2004.

${ }^{57}$ Elmeev V.Ya., Ovsyannikov V.G. Applied Sociology: Essays on Methodology. - 2nd ed., revised and supplemented - St. Petersburg: Publishing house of St. Petersburg State University, 1999.

${ }^{58}$ Veselov Yu.V. Economic Sociology: A History of Ideas. - SPb, 1997; Veselov Yu. V., Matsukova T. K., Petrov A. V. Fundamentals of economic sociology. - SPb., 1998.

${ }^{59}$ Shershneva E.L., Feldhoff Yu. Labor culture in the process of socio-economic transformations: the experience of empirical research at industrial enterprises in Russia. - SPb., 1999.

${ }^{60}$ Kapustkina E.V. Sociology of Entrepreneurship: Traditions and Modernity // Bulletin of St. Petersburg University. Series 6. 2000. - No. 2. - P. 76-83.

${ }^{61}$ Mukhambetov T.I. Motivational mechanism of labor management. - Alma-Ata: Gylym, 1991.

${ }^{62}$ Odegov Yu.G., Nikonova T.V., Bezdelov D.A. Bank personnel management. - M.: REA, 1996. 
addressed by scientists such as K. Zamfir ${ }^{63}$, N.F. Naumova ${ }^{64}$, V.D. Patrushev, I.A. Kalmakan ${ }^{65}$ and others. At the present stage, an important contribution to the study of labor incentives and motivation was made by such scientists as V.A. Mansurov $^{66}$, L.L. Rybakovsky ${ }^{67}$,A.L. Temnitsky ${ }^{68}$, V.V. Radaev ${ }^{69}$, N.I. Dryakhlov ${ }^{70}$, A.V. Tikhonov ${ }^{71}$.

The fourth direction of studying the problem of labor incentives is focused on the study of the quality of labor activity and quality management as a modern direction of management. This direction is represented by the works of such scientists as G.G. Azgaldov ${ }^{72}$, V.G. Versan ${ }^{73}$, A.V. Glichev ${ }^{74}$, E. Deming ${ }^{75}$, A.M. Zherebin ${ }^{76}$, G.D. Krylova ${ }^{77}$, V.M. Mishin ${ }^{78}$, V.V. Okrepilov ${ }^{79}$ and others.

The existing scientific directions of stimulating and motivating labor at the present time do not solve many problems facing management, in particular, the efficiency of labor management of the company's employees.

It should be noted that changes in the position of an organization in modern Russia entailed, first of all, changes in the position of a person in the organization, in the attitude towards him. Awareness of the uniqueness of each employee determined the impossibility of further application of unified management approaches and the need to formulate new management methods aimed at a specific person in a specific situation.

An analysis of modern trends in the personnel management system and its ${ }^{63}$ Zamfir K. Job satisfaction. Sociologist's opinion. - M., 1983.

${ }^{64}$ Naumova N.F., Slyusaryansky M.A. Job satisfaction and some personality characteristics // Social studies. - M., 1970.

${ }^{65}$ Patrushev V.D., Kalmakan I.A. Job satisfaction. - M., 1983.

${ }^{66}$ Mansurov V.A. Social dynamics and transformation of professional groups in modern society. M.: IS RAS, 2007.

${ }^{67}$ Rybakovsky L.L. Applied demography (monograph). - M.: ISPI RAN, 2003.

${ }^{68}$ See: Temnitsky A.L. Theoretical and methodological approaches to the study of labor behavior // Sociological research. 2007. No. 6; Temnitsky A.L. Labor motivation of employees / Economic actors in post-Soviet Russia (institutional analysis). Part 2. Firms of modern Russia. Second edition, revised and enlarged. Ed. by R.M. Nureyev. - M.: MONF, 2003.

${ }^{69}$ See: Radaev V.V. Economic sociology. Course of lectures: Study guide. - M.: «Aspect-Press», 1997; S. What does economic sociology study // Russian economic journal. - 1994. - P. 49-55.

${ }^{70}$ See: Sociology of Labor. Edited by Dryakhlov N.I., Kravchenko A.I., Shcherbina V.V. - M.: Publishing house of Moscow University, 1993.

${ }^{71}$ Tikhonov A.V. Sociology of management. - M., Canon +, 2007.

${ }^{72}$ Azgaldov G.G. Theory and practice of assessing the quality of goods. Basics of qualimetry. - M.: Economics, 1982.

${ }^{73}$ Versan G.G. Integration of product quality management: new opportunities. - M.: Publishing house of standards, 1994.

${ }^{74}$ Glichev A.V. Fundamentals of product quality management. - M.: AMI, 1998.

${ }^{75}$ Deming E. Way out of the crisis. - M.: Alpina Business Books, 2007.

${ }^{76}$ Zherebin A.M. Fundamentals of modern quality management. - M.: New Millennium Foundation, 1998.

${ }^{77}$ Krylova G.D. Foreign experience in quality management. - M.: Publishing house of standards, 1992.

${ }^{78}$ Mishin V.M. Quality and competitiveness management. - M.: 1993.

${ }^{79}$ Okrepilov V.V. Quality control. - M.: Economics, 1998. 
evolution has shown that today the most urgent issue is the management of a single person who can influence the results of the functioning of the entire organization, and even determine them. The predominance of the service sector in the economy affected the change in the specifics of labor, expressed in the transition from mechanized operations to the intellectualization of labor activity, which led to the expansion of the individual tools for the activities of employees, an increase in the quality of their decisions and intensified the problems of the effectiveness of the use of competencies and personal labor potential ${ }^{80}$. Features of labor potential have been studied by scientists since the third quarter of the twentieth century.

Actively studied in the 1970s and 1980s. the problem of motivation was associated with such an issue as the labor potential of a person. «The problem of the orientation (needs, motives, goals) of the personality is inextricably linked with the problem of its abilities (more broadly, the potential of the personality)» ${ }^{81}$.

Until about the mid-70s. the concept of «labor potential» was reduced only to the qualification potential. But already at the end of the 1970s. «Labor potential» began to be considered as a set of personal abilities of an employee to work of a certain complexity and qualifications. A detailed scheme of labor potential was given by N.A. Pavlov, N.A. Ivanov, Yu.G. Odegov, K.L. Andreev, O.V. Stakanova.$^{82}$ According to them, in addition to the personal and productionqualification potential, the psychophysiological potential, which is the mental and physiological data of the employee, also plays a huge role. These are age, gender, type of nervous system, health status, organizational and creative abilities, etc. These scientists attributed to the personal components of labor potential: character traits, production and social activity, and to production and qualification - the level of professional training, the level of labor activity, work experience.

The idea of labor potential was further developed by T.I. Mukhambetov ${ }^{83}$, who in addition to his labor potential distinguish motivational potential. Motivational potential is formed at the junction of labor and personal potentials and is expressed in the form of a level of readiness for effective work. In the process of the development of scientific thought regarding the problems of motivation and incentives, the approach to personnel management also changed.

The interaction of business processes with existing theoretical doctrines led to the evolution of views on the concept of personnel management, the essence of which was transformed from management by instructions to management by goals and further to management by values. The latter type of management is able to

\footnotetext{
${ }^{80}$ Labor potential should be considered as an integral spectrum of elements that make up the employee's productive ability (a combination of physical and creative abilities, knowledge, skills, experience, spiritual and moral values), which characterizes it not only in the present time and state, but also requires consideration of the conditions for its formation and reproduction, as well as prospects for further development.

${ }^{81}$ Lomov B.F. Methodical and theoretical problems of psychology. - M., 1984. - P. 324.

${ }^{82}$ Odegov Yu.G., Bychin V.B., Andreev K.L. Labor potential of the enterprise: ways of effective use. - M., 1991. Part 1. - P.39.

${ }^{83}$ Mukhambetov T.I. Ibid. - P. 52-53.
} 
reconcile the individual goals and values of personnel with the goals and values of the organization, which is a powerful tool for using the employee's labor potential. The effective use of the labor potential of each employee, as well as the creation of organizational conditions aimed at its formation and reproduction, is the actual goal of the personnel management system in modern conditions.

With this understanding of the goals of personnel management, labor incentives becomes the leading tool, which presupposes the process of organizational impact on a person to induce him to appropriate labor actions, which in such a situation acquires special significance, since it allows to generalize and implement a whole range of issues of coordination of social, organizational and individual goals and values. Thus, it is logical to assume that labor incentives, considered as a tool of managerial influence, are the basic element of personnel management.

\subsection{Concepts and approaches to the study of labor incentives}

The concepts of «stimulation» and «stimulus» are by their nature rather complex, and the terms defining them are ambiguous. They have a wide variety of meanings and meanings that convey a person's motivation for action. Diverse understanding of the concept of incentive served as a prerequisite for the formation of different approaches to the definition of «motivation», and, consequently, «stimulation».

Today, there are at least three well-established approaches to the definition of incentives: psychological, sociological and managerial.

The psychological approach is focused on the study of the inner world of the individual, in connection with which it is characterized by a special specificity of the definition of the concept of «motivation». The psychological approach to the problems of motivation is based on the works of such classics of psychology as Z. Freud, K. Jung and other foreign thinkers, in Russia it is presented in the works of L.S. Vygotsky, V.P. Galperin, S.L. Rubinstein and others.

In particular, the creator of the activity approach in psychology S.L. Rubinstein ${ }^{84}$ proved that the psyche and consciousness are formed in activity, in activity and manifest themselves. Activity and consciousness form an organic unity (but not identity). Activity is not a set of reactions to an external stimulus, as it is regulated by consciousness. An important methodological setting for understanding motivation was proved by S.L. Rubinstein the principle of determinism, which explains that external causes act through internal conditions.

The most conceptually complete, reflecting the psychological paradigm, is the approach of A.N. Leontyev. He explains motivation by the fact that each individual is born with certain needs. The need as an internal force can be realized only in activity. In other words, the need initially appears only as a prerequisite, as a condition of activity, but as soon as the subject begins to act, its transformation

${ }^{84}$ See: Rubinstein S.L. Problems of general psychology. - M.: Pedagogika, 1973. 
takes place. The need ceases to be what it was - «a thing-in-itself». In the process of development of activity, this precondition turns into a result. Genetically primordial for human activity is the mismatch of motives and goals. Unlike goals, motives are not always actually realized by the subjects. True, it is possible to motivate them, but the motivation does not always contain an indication of their real motive.

Motives, in turn, are not separated from consciousness. Even when motives are not recognized, that is, when a person does not understand what prompts him to perform certain actions, they find their mental reflection, but in a special form - in the form of the emotional coloring of actions. Some motives, prompting an activity, give it a personal meaning - meaning-forming motives. Others, coexisting with them, playing the role of incentive factors, are deprived of a meaning-forming function - these are motives-incentives. ${ }^{85}$

A person is based on certain mental characteristics that appear before us in the form of needs, interests, aspirations, desires. The desire to realize them leads a person to the need to communicate with each other, to the organization of joint activities.

Based on this approach, the task of stimulating labor activity is to provide a person with the opportunity to satisfy the needs that were originally laid down in him. It is advisable to place accents in labor motivation with a focus on the internal structure of the personality.

The sociological approach to the definition of motivation is expressed in the approach of A.I. Kravchenko. Motivation, in his opinion, is «the process of encouraging oneself and others to act in order to achieve the goals of the organization» or personal goals. ${ }^{86}$

This approach in the study of motivation is based on «understanding» sociology, the theory of social action. M. Weber, R. Merton, T. Parsons are rightfully called the representatives of this sociological approach. M. Weber ${ }^{87}$ believes that a person is motivated by certain goals and values, but, being a social being, he is oriented by expected behavior according to certain rules. According to the concept of T. Parsons ${ }^{88}$, society sets personality social patterns that determine personal motivation. R. Merton ${ }^{89}$ highlighted the main parameters of social motivation: these are goals and values and ethical and technical standards governing social actions.

I.M. Kulintsev believes that human behavior is always determined by his motivations and therefore is the subject of social management. The content of the motive includes a conscious choice of a goal and means of achieving it, takes into account the external environment and conditions of implementation, determines

\footnotetext{
${ }^{85}$ Leontiev A.N. Selected psychological works. In 2 volumes - M.: Pedagogika, 1983.

${ }^{86}$ Kravchenko A.I. Sociology of management. - M., 2004.

${ }^{87}$ Weber M. Basic sociological concepts // Selected works. - M., 1990. - P. 628-638.

${ }^{88}$ Parsons T. System of modern societies. - M., 1997. - P. 134.

${ }^{89}$ Merton R. Social theory and social structure // Sotsis. - 1992. - No. 2, 3, 4. 
$\overline{\text { the lines and program of behavior, and evaluates the possible consequences. }{ }^{90} \mathrm{Ac}-}$ cording to this approach, the stimulation of labor is already a process that is realized not only by those who implement it, but also by those to whom it is directly directed.

The other approach is managerial. It is represented by various definitions and currently does not have one generally accepted one. For example, G.G. Zaitsev will define motivation as «an incentive to active activity of individuals, collectives, groups, associated with the desire to satisfy certain needs. $\nu^{91}$ The managerial definition of motivation combined psychological and sociological approaches from the point of view of managing a person in an organization. The managerial definition of motivation focuses primarily on employee motivation. «Motivation is a combination of internal and external driving forces that induce a person to act, set the boundaries and forms of activity and give this activity an orientation focused on achieving certain goals. $\rangle^{92}$. The well-known American manager Lee Iacocca once remarked: «Management is nothing more than setting other people up for work.» The management process will achieve the greatest efficiency only through solving the problem of labor motivation.

From the point of view of B.Yu. Serbinovsky and S.M. Samygin: «Motivation is the motivation of people to take action. $\nu^{93}$ In this case, stimulation is no longer just a motivation of a person to activity, but also sets the meaning of this activity, thereby bringing the expected result.

Considering the well-established approaches, it should be noted that they do not exist in their pure form. It seems natural that the sciences strive for integration, which predetermines a new approach aimed at describing the motivation and stimulation of a person specifically in work, an approach that combines the achievements of sociology, economics, psychology, management and a number of other sciences - this is the approach of sociology of management. This is also indicated by A.I. Kravchenko in a number of his works and monographs. ${ }^{94}$

Summarizing the above, motivation can be defined as a combination of internal and external forces that induce a person to effective and proactive activities in order to satisfy his needs, set guidelines for this activity and give it a focus on achieving certain goals.

In the activities of people there are always active driving forces that determine their behavior. On the one hand, an urge coming from outside, on the other, self-urge. The factor ${ }^{95}$, that influences the impulses coming from outside is the ${ }^{90}$ Kulintsev I.M. Economics and Sociology of Labor. - M., 1999.

${ }^{91}$ Zaitsev G.G. Personnel Management: Textbook. - SPb.: North-West, 1998. - P. 84.

${ }^{92}$ Vikhansky O.S., Naumov A.I. Management: Textbook for universities. - M.: Higher school. 1994. - P. 65-66.

${ }_{93}^{93}$ Personnel Management: Textbook / Edited by B.Yu. Serbinovsky and S.M. Samygin. - M.: Prior, 1999. - P. 343.

${ }^{94}$ Kravchenko A.I., Tyurina I.O. Sociology of management. - M.: Academic Project, 2004.

${ }^{95}$ A factor (from Latin factor - doing, producing) is a cause, a driving force of a phenomenon, a process that determines its character or its individual features (Russian Sociological Encyclopedia. 
stimulus. «The stimulus - is an external incentive for some kind of activity that does not depend on the employee ${ }^{96}$. Organizations that have achieved impressive results in encouraging their employees to work efficiently and efficiently prove that employee incentives are a prerequisite for the success of the entire company.

According to A.I. Prigogine, «the approach to the problem of labor incentives consists in identifying and comparing, on the one hand, a system of incentives, and on the other, a system of motives and needs to satisfy which these incentives are directed. And to the extent that these counter «streams» are consistent, incentives will be effective. The task of management consists in such impact of stimuli on needs, which would cause appropriate labor behavior for the organization ${ }^{97}$. According to A.P. Egorshin, stimulus is, first of all, «the cause of human behavior ${ }^{98}$, and the stimulation to work is «the cause of human behavior in the labor process $\rangle^{99}$. S.S. Frolov distinguishes stimulus from motive and notes that stimulus is «an external reason that prompts people to take action» ${ }^{100}$.

A similar point of view is shared by N.A. Volgin and O. N. Volgina, who believe that «stimulus is an external incentive to some kind of activity that does not depend on the employee» ${ }^{101}$. V.A. Spivak defines a stimulus as «an event or good that motivates a person or a group of people to perform some action or change their behavior» ${ }^{102}$. In turn, stimulation can be defined as «a method of influencing the work behavior of an employee, mediated through his motivation $\rangle^{103}$. In various incentive models, two main methods are used - positive stimulation (reward) and negative (punishment). The first includes any expression of gratitude, cash bonuses, bonuses, promotions. Negative incentives include reprimand, deduction from wages, loss of bonuses, demotion.

There are many studies in the field of stimulation and motivation (V.A.Yadov, A.G. Zdravomyslov, N.F. Naumova, Yu.P. Kokin, E.D. Katulsky, I.F. Belyaeva and others). Some of them are devoted to the classification of needs, others - to the processes of motivation and incentives.

In the second half of the 90s XX century studies of the problem of incentives and its impact on labor productivity were carried out in the following areas ${ }^{104}$ :

- issues of stimulation for enterprises and organizations of various forms of ownership;

problems of remuneration and its stimulating role in the transition to market

- M., 1998. - P. 539).

${ }^{96}$ Volgin N.A., Volgina O.N. Labor remuneration: Japanese experience and Russian practice. - M.:

Publishing and trade corporation «Dashkov and K», 2004. - P. 41.

${ }^{97}$ Prigogine A.I. Stimulation // Russian Sociological Encyclopedia. - M., 1998. - P. 539.

${ }^{98}$ Egorshin A.P. Work motivation. - N. Novgorod: NIMB, 2003. - P. 10.

${ }^{99}$ Ibid. - P. 11.

${ }^{100}$ Frolov S.S. Sociology of organizations. - M., 2001. - P. 289.

${ }^{101}$ Volgin N.A., Volgina O.N. Ibid.

${ }^{102}$ Spivak V.A. Management. - SPb.: Vector, 2005. - P. 143.

${ }^{103}$ Prigogine A.I. Ibid. - P. 539.

${ }^{104}$ Volgin N.A., Volgina O.N. Ibid. - P. 133-135. 
relations;

- issues of labor productivity, rationing of working hours.

Much attention was paid by researchers to the issues of remuneration in transitional market conditions. L.V. Torgova ${ }^{105}$, after analyzing the issues of monetary incentives, proposed a classification of monetary incentives, which makes it possible to comprehensively consider the essence of monetary incentives and determine the priority of incentives to work in relation to various forms of ownership.

Monetary incentives can be classified according to the following criteria:

- by the time of action:

- continuous;

- discrete.

- by scope:

- nationwide;

- collective;

- personal.

- by functional purpose:

- prestigious;

- encouraging.

- by area of application:

- universal;

- specific.

In the process of functioning of labor motivation, there is a transition from actualized needs, realized through labor activity, to labor behavior. This transition is possible by stimulating labor activity.

In the incentive system, it is especially important to achieve a competent balance between reward, reward and punishment. The negative reaction of the management reduces the employee's activity and the level of his self-confidence. Positive work assessments increase self-esteem and stimulate labor activity. Encouragement allows you to instill confidence in yourself, in your abilities.

Analyzing incentives, A.P. Egorshin highlights the following ${ }^{106}$ :

- (1) coercion, the author names as the most common methods of coercion - administrative, used in modern organizations, which include: remark, transfer to another position, transfer of vacation, reprimand, dismissal from work;

(2) material incentives, including wages and tariff rates, remuneration for results, bonuses from income or profits, compensation, travel packages, loans for the purchase of a car or furniture, loans for housing construction, etc.;

- (3) moral encouragement (incentives aimed at satisfying the spiritual and moral needs of a person): announcement of gratitude, presentation of certificates of honor, honor boards, awarding of honorary titles, degrees, diplomas, publications in the press, presentation of government awards, etc.;

${ }^{105}$ Volgin N.A., Volgina O.N. Ibid. - P. 134.

${ }^{106}$ Egorshin A.P. Personnel Management. - N. Novgorod: NIMB, 2003. - P. 458. 
- (4) self-affirmation - the internal driving forces of a person, prompting him to achieve his goals without direct external encouragement: writing a dissertation, publishing a book, author's invention, building a city (bridge), shooting a film, obtaining a second higher education, etc. Self-affirmation is the strongest incentive known.

There are three main methods of incentives: economic (elements of economic influence), administrative (organizational and regulatory impact) and sociopsychological (use of the social mechanism of management) ${ }^{107}$. These methods can be both positive and negative.

So, the main task of incentives is to become a driving force of activity, and for this the incentive must be unambiguously perceived and understood by the employee, which is not always achieved. So, N.L. Zakharov, considering the employee's assessment of the incentives affecting him, gives the following classification of incentives ${ }^{108}$ :

- motivating stimulus - the stimulus gives the expected effect. In this case, as a result of the action of the incentive, the motivation of the employee (employees) increases, which leads to the planned growth of labor productivity, which remains for a certain time. However, in essence, this is an ideal model, since the employee's real behavior differs from the expected (planned) one. This is because the employee needs to evaluate the incentive, and if it is adequate to the employee's motivation, the manager can hope for the expected productive behavior of the employee.

- non-motivating stimulus - the stimulus has a short-term impact or has no effect at all. This happens in the following cases: (1) incentive is not the key to motivating the employee, that is, the employee cannot evaluate (fully understand) the incentive; (2) the incentive is insignificant (for example, negligible monetary reward); (3) incentive is a means of manipulation, not motivation. Motivational stimulus orients a person to achieve goals in which he is interested, thereby encouraging his productive activity. It is necessary to distinguish between motivation and manipulation: motivation is the incentive of an employee to self-realization in professional activity, and manipulation in certain cases acts as coercion and violence or disorientation (deception). "Violence is not generally compulsion, not generally damage to life and property, but such damage and such compulsion, which are carried out against the will of one or those against whom they are directed $»^{109}$. Manipulative stimulus forces a person to act in accordance with the requirements of the stimulating.

- demotivating stimulus - the stimulus provides a short-term positive effect, and then the employee's actions become protest.

There is also a classification of stimuli, which differentiates them into stimuli

\footnotetext{
${ }^{107}$ Romashov O.V. Sociology of Labor. - M.: Gardariki, 1999. - P. 59.

${ }^{108}$ Zakharov N.L. «The Riddle of the Russian Soul», or Peculiarities of Labor Motivation of Russian Personnel // Personnel Management. - 2004. - No. 22. - P. 35-37.

${ }^{109}$ Guseinov A.A. The concepts of violence and non-violence // Questions of philosophy. - 1994. No. 6. - P. 34 .
} 
$\overline{\text { given by the motivating subject and stimuli perceived by the motivated subject }{ }^{110}}$.

From the point of view of the motivating subject, stimulus can be:

- purposeful or non-purposeful, that is, a motivating subject can plan the influence of a stimulus on a motivated one or get a stimulating effect as a result of random actions;

- effective and ineffective (ie, not giving the expected result);

- direct and indirect (direct incentives imply a direct influence of the motivating subject on the motivated one; there are two main ways of direct incentives: reward and punishment; indirect incentives involve the creation of working conditions).

From the point of view of a motivated subject, stimulus can be as follows:

- conscious or unconscious, that is, the motivated subject may not understand that he is being stimulated to some kind of action;

- internal and external (internal incentives to work can be associated with the physical and psychological state of the employee, while external ones act either as a result of the activity of the motivating subject, or as the influence of the objective external environment).

Logically, other classes of stimulus can be distinguished:

By the degree of interest in the action of the stimulus:

1. personally significant (such stimulus that are of interest to the employee himself, according to his life goals);

2. suggestible (such stimulus that are of interest to the organization, according to the goals of the organization).

By the degree of time of stimulus exposure:

1.Long-term exposure (for example, the possibility of obtaining housing after a certain period of work in the organization);

2. short-term impact (stimulus to perform one-time jobs / tasks).

The correct ratio of long-term and short-term incentives will allow achieving the effect of high-quality performance of tasks by employees and an increase in staff loyalty.

The incentive is usually always associated with a specific situation. Research shows that the relationship between the activity of an employee and the results of his work can be described as a curve. First, as a result of increased activity, the results increase, and then the results remain at a certain achieved level. This stage E.A. Utkin ${ }^{111}$ calls the «optimal range of activity» in which the best results are achieved. After achieving the highest result, activity begins to decline, and the results of work begin to deteriorate. Therefore, a manager must be able to achieve not the maximum activity of employees, but its optimal level.

The motive is the reason, the conscious need to do something. Maintaining motivation at the optimal level is a difficult process, since motives have the peculiarity of transforming under the influence of the characteristics of the ${ }^{110}$ See: Perfilieva M.B. Motivational factors of professional self-actualization of workers: Abstract of the dissertation of the Cand. of soc. sciences. - SPb., 2005. - P. 11.

${ }^{111}$ Utkin E.A. Motivational management. - M.: Teis, 2004. 
personnel, the goals and time set. In this regard, labor incentives plays the main role in maintaining staff motivation.

Labor incentives is aimed at satisfying the needs of staff, that is, it is an offer to the employee what he needs. This process should be seen not only as a shortterm impact on the employee in order to affect his motives, but also as a longterm impact. Short-term motives are associated with the immediate future, a short segment of the activity and its purpose; long-term - with a long-term perspective. The effectiveness of the stimulation increases with an increase in the level of stimulation from short to long.

Labor incentives as a personnel management tool performs the following functions $^{112}$ :

- economic function is expressed primarily in the fact that labor incentives contributes to an increase in production efficiency, which is expressed in an increase in labor productivity and product quality;

moral function is determined by the fact that incentives to work form a life position, a moral climate in the organization and in society as a whole. At the same time, it is important to provide a correct and reasonable incentive system, taking into account traditions and historical experience;

- social function is provided by the formation of the social structure of society through different levels of income, which largely depends on the impact of incentives on different people. In addition, the formation of needs, and as a result, the development of the individual is also predetermined by the organization and stimulation of labor in society.

A.Ya. Kibanov believes that «stimulation as a way of managing the work behavior of an employee consists in a purposeful impact on the behavior of personnel by influencing the conditions of his life, using the motives driving his activities ...». «Stimulation, he emphasizes, is a set of requirements and the corresponding system of rewards and punishments. Incentives presuppose that the management bodies have a set of benefits that can satisfy the needs of the employee that are significant today and now and use them as a reward for the successful implementation of labor functions $\gg{ }^{113}$. Based on this definition, incentives must be carried out not just to induce a person to work, but «to encourage him to do better (more) what is conditioned by labor relations $»^{114}$.

Labor incentives is «...an element of the labor situation that affects human behavior in the world of work, the material shell of staff motivation ${ }^{115}$. Motivation for work is laid down and formed in a person even before the start of his professional activity, «in the process of socialization of the individual by

\footnotetext{
${ }_{112}$ Skopylatov I.A., Efremov O.Yu., Masharov I.M. Personnel management and diagnostics. - SPb.: Znanie, 2002. - P. 185.

${ }^{113}$ Organization personnel management / Edited by A.Ya. Kibanov. - M.: Infra-M, 2004. - P. 490491.

${ }^{114}$ Skopylatov I.A., Efremov O.Yu., Masharov I.M. Ibid. - P. 183.

115 Ibid. - P. 185.
} 
assimilating the values and norms of labor morality and ethics, as well as through personal participation in labor activities within the family and school. At this time, the foundations of the attitude to work are laid..., the working qualities of the individual are developing» ${ }^{116}$. In the process of socialization, a person «acquires the qualities that he needs for life in society, masters social activities, social communication and behavior» ${ }^{117}$.

Stimulation is an impact on a person to induce him to certain actions by activating certain, previously formed motives in him. An interesting question is the ratio of «internal» and «external» motives. A motive is called «internal» if it comes directly from a person who needs to complete a certain task. An example of this type of motivation can be the pursuit of knowledge, the completion of difficult work, etc. «External» motives of labor are wages, orders, etc., associated with the solution of the task, motives coming from the outside.

Another important factor, in addition to the motive, influencing the social action of the individual, is the expectation ${ }^{118}$. The way of choosing a goal or ideal is connected precisely with the expectation of the actions of other people.

The main task of any modern enterprise is to find effective ways of labor management that will contribute to the development of human resources. The most important aspect that affects the efficiency of personnel is the stimulation of labor, a certain model of which exists in every enterprise or firm. It represents the interrelated principles and factors that induce employees to work highly productive, thereby ensuring the productive operation of the entire system.

It is known that motivation has a significant and decisive influence on the performance of a person's work.

The simplest model of the incentive process includes three elements:

1. Conscious relationship by a person of his needs and expectations (income level, desire for respect, etc.) with the environment.

2 . The very behavior of the individual. In the process of striving to satisfy his needs, a person chooses a certain line of behavior. There is a process of moving the individual towards the goal.

\section{Satisfaction of needs.}

Research has shown that people only work to their fullest when they are confident that their efforts will be properly rewarded. The manager's task is to provide employees with the opportunity to meet the full range of their needs in exchange for their work and skills. In this situation, the effectiveness of the management ${ }^{116}$ Ibid. - P. 184.

${ }^{117}$ See: Volkovitckaia G.A. The interaction of family and school in the process of socialization of children. // World of childhood: metaphysics of the cultural and civilizational crisis. - SPb.: Asterion 2006. - P. 406.

${ }^{118}$ Expectation is a term that in theory (and in structural functionalism in general) denotes a person's expectation of a certain behavior, depending on his position (position) in the social system. This position itself appears as a system of expectations presented to a person by society and provided with appropriate sanctions and rewards, the rules of social interaction. (See: Shikhirev P.N. Expectation // Russian Sociological Encyclopedia. - M., 1997. - P. 630). 
style plays an important role. Efficiency consists of many components: these are the potential capabilities of the organization, the general competitive situation, the abilities of the leader himself $\mathrm{f}^{119}$.

Stimulating an employee as a process can be represented as a series of sequential stages ${ }^{120}$.

The first stage is stimulation to activity (usually external).

The second stage is the person's assessment of the stimulus and correlating it with his expectations and needs.

The third stage is the actualization of needs under the influence of a stimulus and the correlation of the actualized need with the conditions of the social environment, which is manifested in the assessment of the possibility of satisfying or not satisfying the need. At this stage, social regulators and organizational conditions are of great importance, which influence personal choice. The nature of the assessment is influenced by the way of assessment (and more broadly - the style of thinking of the individual, for example, the rational assessment of reality).

The fourth stage - a person, focusing on his style of thinking, searches for ways to realize the need, finds the goals (direction) of action, in what ways and what kind of need can be provided. It determines what needs to be obtained in order to satisfy the need.

The fifth stage is the choice of actions in accordance with your style of thinking.

The sixth stage is an action in order to obtain the desired result.

Stimulus as an instrument of influence is directly focused on the need, its satisfaction, while the motive is a kind of connecting link between the need and the stimulus. For this connection to appear, the incentive must be understood and accepted by the employee.

In the process of turning a stimulus into a behavior-determining motive, the stimulus can be accepted or rejected by the subject. If the stimulus is accepted, it is quickly updated. This is possible if there is an appropriate attitude, which may be past experience or a person's predisposition to certain actions in specific situations. The attitude characterizes the stereotyped perception of the stimulus from the standpoint of the possibility of satisfying the need. It's a kind of automatism of actions ${ }^{121}$.

Another, more prolonged process of stimulation takes place when an employee finds himself in a new situation for which he does not have an appropriate attitude. In this case, the rational-evaluative process plays a special role, including the evaluation of the information in the stimulus and the evaluation of the ability to satisfy the actual need.

The actualized motive represents the impetus, the very reason for the behavior

\footnotetext{
119 Zakharov N.L. The effectiveness of the management style («non-ideological» assessment) // Personnel management: theory and practice: Materials of the All-Russian scientific and practical conference. - SPb.: Book House, 2004. - P. 5-9.

${ }^{120}$ Zakharov N.L. Foundations of the regulatory (sociocultural) concept of motivation. - SPb., 2004.

${ }^{121}$ Travin V.V., Dyatlov V.A. Fundamentals of personnel management. - M.: Delo, 1995. - P. 101. 
and completes the stimulation process.

Taking into account the head of the organization of the mechanism of motivation helps to choose the most competent forms and methods of incentives. The described mechanism of motivation shows only the general elements of the motivational process and does not give definite ideas about the formation or strength of motivational action and its influence on a person's labor behavior ${ }^{122}$.

However, knowledge of the logic of the incentive process does not provide global advantages in managing this phenomenon due to the lack of obvious motives. One can only guess which motives are leading, but it is difficult to define them unambiguously. The motivational process is constantly transforming and depends on those needs that are leading for it at the moment. In this regard, its various changes and transformations are likely. It is also necessary to consider the fact that motivational structures are different for different people. Hence follows the differentiated degree of influence of some stimuli and others.

Summarizing the considered problems, it should be noted that the process of implementing managerial influences on personnel is based on the use of various driving forces that induce proactive and purposeful activities, which are, first of all, motives and incentives. The complex nature of the emergence and nature of the influence of various incentives and motives predetermines a different degree of effectiveness of management influences, that is, different results of incentives, based not only on the specifics of the subject (personnel management system) involved in the incentive process, but also on the object of management (employee) itself.

In the activities of people there are always active driving forces that determine their behavior. On the one hand, it is an urge coming from the outside, and on the other hand, self-urge. The factor influencing the impulses coming from the outside is the stimulus.

In various incentive models, two main methods are used - positive stimulation (reward) and negative (punishment).

The incentives themselves are diverse both in action and in result.

Summing up, we can say that labor incentives is «an influence on the motivational structure of an employee's personality through directed managerial influence, in order to obtain a certain result, which in modern conditions becomes the employee's ability to accumulate and effectively use the existing labor potential in accordance with the goals and values of the organization ${ }^{123}$.

The incentive system is «a set of measures of managerial influence on personnel, aimed at agreeing and harmonizing the goals and directions of development of the personnel management system with the directions of development of the

\footnotetext{
${ }^{122}$ Kardashov $V$. Personnel motivation: theory and practice // Man and labor. - 2002. - No. 10. - P. 81.

${ }^{123}$ See: Volkovitckaia G.A. Stimulation of labor as a method of enhancing labor potential. // Management of the XXI century: strategies, technologies, human resources. - SPb.: LLC «Book House», 2009. - P. 55.
} 


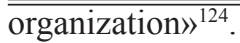

The purpose of the labor incentive system is to harmonize the methods and forms of labor incentives with the main goals and directions of development of the personnel management system and the organization as a whole.

\subsection{Parameters and characteristics of a high-quality personnel incentive system}

In the process of labor incentives, the organization and the employee interact. The consumer of the incentive system is, on the one hand, the organization itself that develops this system, focusing on its tasks and potential opportunities, and on the other hand, an employee who is a directly interested person, since he comes to the company in pursuit of his goals. First of all, the results of the activity of the entire organization depend on what this interaction will be, how it will be formed and built.

In order to make incentive systems of high quality and effective, it is necessary to ensure control over their application in the process of their construction. Before talking about high-quality incentive systems and their design, it is necessary to analyze the very concept of «quality». This concept itself contains many aspects and elements.

Quality is one of the most important philosophical categories, which was considered in the works of Aristotle, B. Spinoza, K. Marx ${ }^{125}$. Despite the fact that research in the field of quality has been going on for a long time, there is still no single approach to defining the concept of quality.

All the variety of definitions of the category «quality» can be combined into the following groups ${ }^{126}$ :

- quality as an absolute assessment (in this common meaning, quality is synonymous with excellence);

- quality as a property of an object (in this meaning, quality is derived from any measurable quantitative parameter of an object or phenomenon);

- quality as conformity to value (as fitness for use);

- quality as a correspondence to cost (quality as a ratio of utility and cost);

- quality as compliance with standards.

The systemic concept of quality is reflected in the definition of the Great Soviet Encyclopedia. «Quality is an essential certainty of an object or process, acting in its properties and characterizing the fact that a given object or process appears in given conditions, in connection and interaction with other given objects and

${ }^{124}$ Ibid. - P.55.

${ }^{125}$ See: Aristotle. Metaphysics // Works: In 4 volumes - M.: Mysl. - Vol. 1.176; Spinoza B. Ethics // Selected works: In 2 volumes - M., 1957. - Vol. 1; K. Marx, To the Critique of Political Economy // K. Marx, F. Engels - Works. In 37 volumes - Vol. 3.

${ }^{126}$ Gromova L.A., Trapitsyn S.Yu., Timchenko V.V. Quality of education in the context of the UNESCO Education for All program: Russian edition: Recommendations based on the results of scientific research. $-\mathrm{SPb} ., 2006$. - P. 22-24. 
processes». ${ }^{127}$

G.G. Azgaldov introduced another term into everyday life: «quality is a complex property, which is a combination of all those and only those properties that characterize the results obtained when consuming an object (both desirable, positive, and undesirable, negative)» ${ }^{128}$.

In the S.I. Ozhegov's Dictionary of the Russian language S.I. Ozhegov's quality is interpreted as «the presence of essential signs, properties and features that distinguish one object or phenomenon from others» ${ }^{129}$.

To assess and determine the quality of incentive systems, the most applicable is the definition of this concept by G.G. Azgaldova, assessing the quality from the standpoint of the results obtained in the process of using the object. From the point of view of incentives, such results can be: an increase in productivity when introducing incentive policies, an improvement in the moral and psychological climate, an increase in organizational loyalty, a decrease in staff turnover, an increase in the creative component of labor, etc.

Based on the multiplicity of approaches in defining «quality», the requirements for the organization of a high-quality incentive system can be represented as a series of requirements ${ }^{130}$ :

- complexity ${ }^{131}$ of the system. It implies the unity of economic, administrative and socio-psychological incentives, the ratio of which depends on approaches to personnel management, experience and traditions of the enterprise. Complexity also presupposes the presence of disincentives;

- differentiation of the system. Means an individual approach to stimulating different layers and groups of workers;

- flexibility and efficiency of the system. Constant revision of incentives, depending on the changes taking place in society and the team.

In order to maximize the effect of the incentive system, certain principles must be followed ${ }^{132}$ :

- availability. Every incentive must be available to all employees. The conditions for incentives must be clear;

- perceptibility. Different incentives affect different people in different ways, this principle must be taken into account when determining the lower threshold of the incentive;

gradualness. Economic incentives are subject to constant adjustment, and this must be taken into account in practice. Once highly increased remuneration, ${ }^{127}$ Great Soviet Encyclopedia. Vol. 11. P. 551.

${ }^{128}$ Azgaldov G.G. General information about the methodology of qualimetry // Standards and quality. - 1994. - No. 11. - P.25.

${ }^{129}$ Ozhegov S.I. Dictionary of the Russian language / Edited by N.Yu. Shvedova. - 12th ed. - M.: Russian language, 1978. - P. 249.

${ }^{130}$ Skopylatov I.A., Efremov O.Yu., Masharov I.M. Ibid. - P. 185-187.

${ }^{131}$ Ibid. - P. 184.

${ }^{132}$ Goryachev S. System of labor motivation: principles of construction // Entrepreneurship. - 2005. - No. 2. - P. 40-53. 
which is not subsequently confirmed, will negatively affect the employee's motivation due to the formation of an expectation of increased remuneration and the emergence of a new lower incentive threshold that would be acceptable to the employee. At the same time, a decrease in the level of material incentives is not allowed;

- minimization of the gap between the results of work and its remuneration. The simultaneous action of the stimulus has been noticed for a long time. Experiments have shown that adherence to this principle can even reduce the level of remuneration, since many employees prefer «less is better, but right away». The increase in reward, its direct connection with the real result is a strong motivator. An increase in the level of remuneration in relation to the previous one brings the employee both material and moral satisfaction;

- a combination of monetary, administrative and socio-psychological types of incentives. By their very nature, all of these species are equally powerful and effective. It all depends on the place, time and subject of the influence of these incentives: the scope of the organization, the financial situation and the characteristics of the activity of a particular employee. Taking into account this circumstance, it is necessary to correctly combine these types of incentives, taking into account their purposeful action on an individual employee. Underestimation or overestimation of any type of incentive leads to a decrease in the efficiency and quality of personnel, which in turn is dangerous for the entire organization;

a combination of incentives and disincentives. Here we are talking about dismissal, reprimand. It is a known fact that negative motivation acts as a kind of mobilizing factor of activity.

One of the main indicators of the quality of the incentive system is the assessment of the effectiveness of labor incentives. When considering the issue of assessment, we will single out general and specific aspects of this problem. Effectiveness is defined as «the ability to have an effect, to have an effect». The concept of «labor efficiency» is defined as the most important economic indicator that characterizes the productivity of the labor activity of people; expressed in achieving the greatest effect with minimal labor costs.

With regard to assessing the effectiveness of labor incentives, one can restrict ourselves to an estimate of costs equal to the costs of the enterprise (firm) for remuneration of labor. In this case, the problem of labor efficiency can be transferred to the «plane» of enterprise efficiency, since the implementation of labor incentives is associated with costs, and any stimulating effects should lead to an increase in labor productivity and an increase in production efficiency. All this should ultimately lead to an increase in the organization's revenues to such a level that would allow not only to cover the costs of using a certain incentive system, but also to make a profit in excess of this. Thus, an important characteristic of a quality incentive system is its self-sufficiency.

As a research problem, the process of developing a labor incentive system, 
$\overline{\text { which is subject to certain rules, is of particular interest. Among the rules for }}$ developing an incentive system, it is necessary to highlight those that maximally affect the motivation of employees ${ }^{133}$.

Building an incentive system on a scientific basis.

The development of a high-quality incentive system cannot fail to take into account the achievements of scientific theories in the field of labor motivation. To date, two main directions of motivational theory have already developed and are recognized: procedural and substantive. Each of them, based on the advanced achievements of various branches of science, contributed to the theory and practice of motivation and incentives.

Along with the emergence of scientific management, a social need arose for theories aimed at developing science-based personnel management mechanisms, or incentive mechanisms. The empirical experience of F. Taylor, G. Ford, Frank and Lilia Gilbrets, and then E. Mayo, accumulated in the first decades of the twentieth century, discovered a number of aspects of staff incentives and served as a prerequisite for the formation of a procedural approach in the theory of motivation. F. Taylor, for example, studied labor operations of workers. The Gilbrets, in turn, invented the device and gave it the name «microchronometer», which they used in conjunction with a movie camera in order to determine exactly what movements are performed during specific operations and how long each one takes. Henry Ford created an optimal system for organizing labor operations of workers - a conveyor belt. The achievements of the named scientists caused the emergence of a social order for applied theories of motivation and labor incentives and became a prerequisite for the creation of a procedural approach in the theory of motivation and incentives.

The intellectual impetus for this approach was given by Kurt Levin's «field theory ${ }^{134}$ (30s of the twentieth century), describing the factors that determine human behavior. According to this theory, the course of actions is completely determined by the totality of conditions of the field existing at a particular moment. The concept of a field covers the causes (factors) of both external (environment) and internal (subject) situations. K. Levin proposes, when analyzing the behavior of an individual, to proceed from an integral situation, which must be reconstructed as it appears to the subject. This means that the explanation of the behavior and the situation must be psychological. Another characteristic of Levin's theory is as follows: simple connections in the meaning of the «stimulus-response» association are not enough to explain behavior; it must be taken into account that behavior is influenced by what acts here and now, within the existing field. To explain behavior, $\mathrm{K}$. Levin developed models that partially complement each other: personality and environment. Also of great importance for understanding motivation was the idea

${ }^{133}$ Goryachev S. Ibid. - P. 40-53.

134 See: Levin K. A Dynamic Theory of Personality. N.Y., 1935; Levin K. Principles of Topological Psychology. L. 1936; Levin K. Field Theory in Social Science. N.Y., 1951; Heckhausen H. Motivation and Activity. - SPb.: Peter; M.: Smysl, 2003. 
of dividing human behavior into volitional and field.

The procedural approach became quite productive and was further developed in the theory of expectations by V. Vroom (1960s) ${ }^{135}$. According to this theory, a person expects certain behavior from others, depending on his position in the team. Not only one need is a necessary condition for stimulating a person to achieve a set goal, but also the type of behavior chosen by him.

Procedural expectation theories illustrate that employee behavior is determined by behavior:

1. a leader who stimulates the employee's work;

2. an employee who expects to receive a reward;

3. an employee and a manager who assume that improving the quality of work will lead to a certain reward;

4. an employee who compares the amount of remuneration received with the amount that will allow him to meet the needs.

According to the theory of expectations in relation to the problem of labor incentives, the manager should provide such rewards that can satisfy the urgent needs of the employee.

In the theory of justice by R. Adams (1965) ${ }^{136}$ the effectiveness of an incentive is assessed by an employee not by a group of factors, but by taking into account the assessment of remuneration given to other employees working in a similar work situation.

An employee evaluates his or her remuneration against the remuneration of other employees, taking into account the working conditions. For example, one runs on newer hardware and the other does not. In this case, one will have one product quality, and the other will have another. Thus, a person's actions are focused on his desire for equality in relations with other people in his environment.

The theory of expectations and the theory of justice was synthesized by the concept of L. Porter and E. Lawler (second half of the twentieth century) ${ }^{137}$ in which the relationship between the reward and the results obtained was introduced.

L. Porter and E. Lawler introduced variables that affect the amount of remuneration: the applied efforts, the qualities of a person's personality and his awareness of his role in the labor process. Expectation theory and equity theory are that the employee estimates his remuneration in accordance with the effort expended and expects that the remuneration will be equivalent to the effort expended.

The need to develop incentive mechanisms that would affect a person's inner urge to action led to the formation of a meaningful approach in the theory of

\footnotetext{
${ }^{135}$ Vroom V.H. Motivation in Management. - N.Y., 1965; Falmer R.M. Encyclopedia of Modern Management. - Vol. 1. - M.: Finance and statistics, 1992. - P. 45.

${ }^{136}$ See: Adams J.S. Inequity in Social Exchange // Advanced in Experimental Social Psychology. v.2. - N.Y., 1965; Kasyanenko O.A., Melnikova M.N., Potemkin V.K., Spivak V.A., Slobodskoy A.L. Work motivation. - SPb., 2003. - P. 18.

${ }^{137}$ Porter L.W., Lawler E.E. Managerial attitudes and performance. - Homewood, 1968. 
motivation and the development of concepts by D. McClelland, F. Herzberg, A. Maslow and others. These concepts from different angles, but quite fully characterize human needs, the nature of functioning and the mechanism of maturation of a person's inner motivation, its structure.

The formation of a meaningful approach was greatly influenced by the practical experiments of E. Mayo (1927-1932) $)^{138}$, in particular the Hawthorne experiments in Chicago. The experiments were carried out in order to understand how the working conditions influence the labor productivity (in particular, the experiment was carried out with the level of illumination). As a result, the following conclusions were made: the level of illumination does not affect labor productivity as much as constant control over workers.

An essential feature of Mayo's work is his negative attitude towards social conflict. He believed that industrial unrest was due to personal problems, both physiological and mental. So, for example, he believed that the source of industrial unrest is not so much the desire of workers to comply with their legitimate economic or group interests, as their pessimistic inner attitude. Accordingly, the refusal of the individual to obey one or another of the requirements of the leader was viewed by Mayo not as one of the inevitable moments in the work of production, but as a manifestation of his, the individual, mental instability or unmet needs. In evaluating the results of experiments carried out in the experimental assembly area, Mayo deliberately neglected the influence of material incentives on the behavior of pickers and focused on group cohesion and unobtrusive leadership.

On the basis of the Hawthorne experiments, E. Mayo and his colleagues put forward the concept of «human relations». It is based on the following ideas;

- a person is a social being,

- leaders of organizations should focus on meeting the needs of people,

- the needs of employees include not only material, but also social interests and aspirations.

Just as the ideas of scientific management became associated with the name and works of F.W. Taylor, the study of the relationship between members of the production team and the social aspects of the individual, which became the threshold of a new era in management theory, began to be associated with the figure of Elton Mayo.

However, not everyone remembers that the famous English socialist Robert Owen (1771-1858) became a pioneer in the study of the influence of sociopsychological factors on the increase in labor productivity. As director of a number of textile factories in New Lenark, Scotland, Owen from 1800 to 1828. conducted an experiment aimed at humanizing the relationship between entrepreneurs and employees. R. Owen improved working and living conditions, organized trade in shops for workers at affordable prices, opened schools, etc. Owen was also

\footnotetext{
${ }^{138}$ Mayo E. The Social Problems of an Industrial Civilization. - L. 1949; Vesnin V.R. Management.
} - M.: Prospect, 2004. - P. 50-51. 
the first to recognize the importance of motivating workers. One day he came to a factory with three types of ribbons: green, yellow and red. He tied red ribbons to the machines of well-performing workers, green ribbons to the machines of workers with average output, and yellow ribbons to the machines of workers who did not meet the established norms. The workers understood this immediately and after two months they all had red ribbons. So, without increasing wages, Owen achieved an increase in labor productivity. Owen reflected his experience in the book «A New Look at Society, or Experience on the Principles of Human Character Education» (1813).

Such practical experience became the starting point in the creation of theories of the needs of the individual and the beginning of meaningful theories of motivation, the creators of which believed that a person would not work productively if, as a result of his professional activity, he could not satisfy his needs, and that the construction of incentive systems should be based precisely on this postulate.

The first of the considered theories is the hierarchy of needs of A. Maslow (1934-1954) $)^{139}$. Its essence boils down to the study of human needs. According to Maslow, human behavior is based on needs, which can be divided into several groups:

1. physiological needs;

2. the need for security and confidence in the future;

3. social needs;

4. the need for respect, recognition;

5. the need for self-actualization and self-expression.

The first two groups of needs are primary, and the remaining three are secondary.

According to A. Maslow's theory, needs can be arranged in a strict hierarchical sequence, in the form of a kind of pyramid, the base of which is primary needs, and the top is secondary. The meaning of such a stepwise construction is that the needs of lower levels are prioritized for a person and this lays an imprint on his motivation. In other words, the most decisive factor in human behavior is the satisfaction of needs at first low levels. Further, as these needs are satisfied, the needs of higher levels become a stimulating factor in labor activity.

The highest need - the need for self-expression and personal growth of a person - can never be fully satisfied, and therefore the process of stimulating a person through his needs is endless.

In this case, the task of incentives should be defined as the management of unmet personnel needs. It is the duty of every manager to find out in a timely manner what active needs drive employees, and to contribute to their implementation in order to improve the quality of employees' work.

David McClelland's Theory of Motivation (1961) ${ }^{140}$. In the process of

\footnotetext{
${ }^{139}$ See: Maslow A. Ibid.

${ }^{140}$ McClelland D.C. Power: The Inner Experience. - N.J., 1975. 
$\overline{\text { development of economic relations, an important role in the theory of motivation }}$ began to be assigned to the needs of high levels. The representative of this theory is David McClelland. According to his position, the structure of the highest level needs is reduced to the following elements: the desire for success, the desire for power, the desire for recognition. In this case, success is seen not as praise or recognition of colleagues, but as personal achievements in the course of active work, as a willingness to make difficult decisions and take personal responsibility for them. Recognition is seen as the ability to be a leader, to have your own opinion, and power is seen as the ability of a person to work productively at various levels of management in an organization.

Labor stimulation in this case comes down to managing these needs by preparing employees for moving up the career ladder to new positions through certification, referral to advanced training courses, etc.

The theory of motivation by Frederick Herzberg (1959) appeared in connection with the growing need to determine the influence of material and moral factors on a person's motivation for activity. Frederick Herzberg created a two-factor model that reflects job satisfaction.

The first group of factors (hygienic factors) is associated with the environment in which the work is carried out and with the working conditions. Hygiene factors correspond to physiological needs. The second group of incentive factors is associated with the essence and content of the work itself. Job satisfaction is determined by factors such as the ability to move up the career ladder, the ability to achieve recognition, etc.

According to this theory, productivity and quality of work can be achieved by organizing work in such a way that the employee is aware of the importance and complexity of the work he is doing, responsibility, so that there is no monotony of the operations performed.

Thus, meaningful theories of motivation are based on the study of needs and the discovery of factors that determine the behavior of people, that is, they affect a person's inner urge to action. A feature of the procedural approach is that it describes the processes of social actions of a person from an external point of view, i.e. focused on the development of mechanisms of external influence.

The construction of an incentive system should take into account and competently coordinate the influence of the incentive on the motive, since only if the incentive and motive coincide, the effectiveness of the activities of both the organization and the personnel will be maximum.

In practice, a combination of various forms of incentives is widely used, most often resorting to a combination of monetary and non-monetary forms of incentives, which significantly enhances their effect. This combination is typical for the professional promotion system. Non-cash forms of remuneration are an additional form of remuneration. Although their share in the structure of remuneration is relatively small, the stimulating effect and impact on the economic behavior of 
workers is very significant.

The experience of using non-monetary forms of remuneration in Russia and in Western countries allows us to draw the following conclusion: as a rule, the role and significance of non-monetary forms of remuneration increases with the growth of the level of monetary income and the growth of the creative component of labor activity.

Other rules for developing a high-quality labor incentive system include the following ${ }^{141}$ :

- real consideration of the interests of employees, which includes the objective characteristics of their activities. The labor incentive system will be effective to the extent that it corresponds to the real interests of its employees;

- the system of labor incentives must be built on the foundation of mutual responsibility of the organization and each employee, with clear and consistent observance of their mutual obligations. It is fundamentally important that the obligations of employees to the organization and its obligations to them correspond to each other, would be balanced both from the professional and moral points of view;

- the labor incentive system should ensure an appropriate lifestyle for employees, creating favorable conditions for the reproduction of their workforce and contributing to the fullest disclosure of the employee's personality potential;

- the labor incentive system should provide effective social protection to employees.

Focusing on the variety of existing classifications of incentives that characterize the focus and strength of managerial influence on the employee, it becomes possible to formulate the following indicators of the quality of incentive systems:

- the importance of organizational incentives (the presence in the incentive system of a complex of organizational incentives endowed with a value-significant coloring for the majority of employees who are able to meet urgent needs, which provides a stimulating nature for managerial influences);

- the optimal ratio of direct organizational incentives (wages, bonuses, etc.) and indirect impact (working conditions);

- the optimal ratio of organizational incentives of long and short-term impact (orient the activities of employees towards the implementation of short-term and long-term goals and prospects);

- unambiguous perception of organizational incentives (incentives of the incentive system should not only be accepted by the majority of employees, but also correctly understood and evaluated by them);

- purposefulness of the influence of organizational incentives (not spontaneously arising, but implemented in accordance with the main goals and directions of development of the personnel management system).

Thus, the construction and development of such incentive systems must meet

${ }^{141}$ See: Goryachev $S$. Ibid. - P. 40-53. 
the following requirements: the complexity of the system, the differentiation of the system, as well as the flexibility and efficiency of the system, which consists in the constant revision of incentives depending on the changes taking place in society and the work collective.

At the same time, the construction and development of incentive systems should take into account the existing experience, features and specifics of the organization's activities and be designed on a scientific basis.

Summarizing the considered problems of the first chapter, it should therefore be determined that

1. Stimulus - is an external incentive to some kind of activity, independent of the employee.

2. Motivation - is a combination of internal and external driving forces that induce a person to effective and proactive activities in order to satisfy his needs, set the boundaries and forms of activity and give this activity an orientation focused on achieving certain goals.

3. Focusing on the variety of existing classifications of incentives that characterize the direction and strength of managerial influence on the employee, it becomes possible to formulate the following indicators of the quality of incentive systems:

- the importance of organizational incentives (the presence in the incentive system of a complex of organizational incentives endowed with a value-significant coloring for the majority of employees who are able to meet urgent needs, which provides a stimulating nature for managerial influences);

- the optimal ratio of direct organizational incentives (wages, bonuses, etc.) and indirect impact (working conditions);

- the optimal ratio of organizational incentives of long-term and shortterm impact (they carry out the orientation of employees' activities towards the implementation of short-term and long-term goals and prospects);

- unambiguous perception of organizational incentives (incentives of the incentive system should not only be accepted by the majority of employees, but also correctly understood and evaluated by them);

- purposefulness of the influence of organizational incentives (not spontaneously arising, but implemented in accordance with the main goals and directions of development of the personnel management system).

Currently, the economic nature of labor remuneration has fundamentally changed. Labor remuneration is understood as «the totality of material and other benefits received by the employee as a result of his participation in the labor process». ${ }^{142}$ Labor remuneration (and, above all, wages) has always been and remains for most members of society the basis of their well-being.

There are various systems of labor incentives. The leadership of modern organizations independently sets the forms, systems and amounts of labor

${ }^{142}$ See: Labor Economics / Edited by M.A. Vinokurova, N.A. Gorelova. - SPb.: Peter, 2004. - P. 229. 
remuneration. At the same time, it is possible to use the ratios laid down in the previously valid tariff rates as guidelines for differentiating earnings depending on the profession, qualifications, complexity and working conditions. The most important task is to establish the relationship between the wages of each employee with the quantitative and qualitative results of work.

A condition for high efficiency of labor remuneration is a systematic approach to the development and application of incentive systems, taking into account:

- the complexity of the system (the unity of economic, administrative and socio-psychological incentives, the ratio of which depends on approaches to personnel management, experience and traditions of the enterprise);

- differentiation of the system (means an individual approach to stimulating different strata and groups of workers, based on their real interests and needs);

- flexibility and efficiency of the system (constant revision of incentives depending on changes in society and the team).

Knowledge of the logic of the incentive process does not provide decisive advantages in managing this phenomenon. An important factor here is the nonobviousness of the motives. It is very difficult to identify which motives are leading in the motivational process of a particular person and in specific conditions.

A very important factor is the constant transformation of the motivational process. Its character depends on what needs initiate it. The needs themselves are in a complex dynamic interaction, often contradict each other. The components of this interaction are capable of changing over time, changing the direction and nature of the action of motives. Hence, even with a deep study of the motivational structure of a person, the system of his action, completely unforeseen changes in human behavior and an unexpected reaction to stimulating influences are possible. Another important factor is the difference in the motivational structures of different people, different degrees of exposure to the same stimuli, different degrees of dependence of the action of some stimuli on others.

Thus, in order to develop a labor incentive system that meets quality indicators, first of all, it is necessary to study the typology of personnel in order to determine the nature of the impact of the complex of existing incentives that determines the effect of managerial influence (result). With the help of a systematic approach, it becomes possible to ensure a competent choice by the management of effective forms of incentives, the correct determination of the degree, nature and speed of the impact of incentives on employees, that is, to set the management impact of a targeted stimulating character in accordance with the goals and directions of development of the personnel management system and the organization as a whole. 